in vivo $31: 291-302(2017)$

doi:10.21873/invivo.11058

Review

\title{
Laparoscopic Splenectomy for Benign Hematological Disorders in Adults: A Systematic Review
}

\author{
DEMETRIOS MORIS ${ }^{1}$, NIKOLETTA DIMITRIOU ${ }^{2}$ and JOHN GRINIATSOS ${ }^{2}$ \\ ${ }^{1}$ Department of Surgery, The Ohio State University Wexner Medical Center, Columbus, OH, U.S.A.; \\ ${ }^{2}$ First Department of Surgery, National and Kapodistrian University of Athens, \\ Medical School, Laikon General Hospital, Athens, Greece
}

\begin{abstract}
Background: Since its introduction in the early 1990s, laparoscopic splenectomy (LS) has gained worldwide acceptance for spleen removal, especially in hematological patients. Aim: The present review summarizes the current knowledge and results of LS for the treatment of benign hematological diseases in adults. Materials and Methods: A MEDLINE/PubMed database research was performed using the terms: "laparoscopic splenectomy" OR "laparoscopy" OR "splenectomy" AND "hematological disorders" OR "hematological disease" OR "hematology" AND "adults" as key words. We set our analysis starting date as January 1 st 2010 and the end date as December 31st 2016. We identified 247 relative articles. All the references from the identified articles were searched for relevant information. Results: Twenty-seven articles were deemed appropriate for our analysis. LS was found to be feasible and safe in the majority of patients with benign hematological disorders, with a mortality rate ranging from $0 \%$ to less than $4 \%$ and the postoperative complications rate from $0 \%$ to $35.7 \%$. The conversion rate was also very low (4\%) and response (complete or partial) was achieved in more than $80 \%$ of patients. Lateral approach with four trocars was the most commonly used approach with concommitant cholecystectomy being correlated with increased operative time and morbidity. Conclusion: Current literature holds that whenever
\end{abstract}

This article is freely accessible online.

Correspondence to: Demetrios Moris MD, M.Sc., Ph.D., Department of Surgery, The Ohio State University Comprehensive Cancer Center, The Ohio State University, Columbus, OH, 43210. U.S.A. Tel: +1 2164442574, Fax: +1 2164454658, e-mail: dimmoris@yahoo.com

Key Words: Laparoscopic splenectomy, laparoscopy, splenectomy, hematological holds disorders, hematology, adults, review. splenectomy is required for the treatment of hematological disorders in adults, a laparoscopic approach should be offered as the gold standard. However, to strengthen the clinical evidence in favor of LS, more high-quality clinical trials on several issues of the procedure are necessary.

Since its introduction in 1991 (1), laparoscopic splenectomy (LS) has gained worldwide acceptance for surgical removal of the spleen in patients with hematological diseases. It has been reported that the method can be performed safely and effectively, with low rates of mortality and morbidity, reducing postoperative pain and offering a superior cosmetic appearance compared to open splenectomy (OS) $(2,3)$. However, the advantages of the laparoscopic method were not stated sufficiently and randomized clinical trials to evaluate the role and efficacy of the approach are mandatory. Setting the article of Mikhael et al. (4) as the baseline of our analysis, we reviewed all emerging literature on the subject of LS in hematological diseases in adults evaluating its feasibility, efficacy and surgical details, as well as morbidity and mortality rates in an attempt to answer all current debates on this subject.

\section{Materials and Methods}

The MEDLINE/PubMed database was searched for publications with the medical subject heading "laparoscopic splenectomy" and key words "laparoscopy" OR "splenectomy" AND "hematological disorders" OR "hematological disease" OR "hematology". Two independent reviewers (DM and ND) performed the literature search, the study selection and the data extraction. We identified 247 relative articles. We set our analysis starting date as January 1st 2010 since previous bibliography was covered by the review of Mikhael et al. (4), and the end date of the review was December 31st 2016. This systematic review was conducted in accordance with the Preferred Reporting Items for Systematic Review and Meta-Analyses guidelines (5). Additionally, the references of the identified articles were searched for relevant information. When articles referred to repeat investigations evaluating the same study 
population, the most recent study was included. After removing duplicates, the remaining articles were available for screening.

We excluded articles that were not written in English or articles whose full-texts and abstracts were not accessible or comprehensive, and articles referring to pediatric populations from further analysis, as well as editorials, expert's opinions, reviews, meta-analyses and animal studies. After applying the above criteria, 27 articles were deemed appropriate for further analysis and were included in the present study.

\section{Results}

Indications. Benign hematological diseases such as idiopathic thrombocytopenic purpura, thrombotic thrombopenic purpura, HIV-related thrombocytopenia, hereditary spherocytosis (HS), autoimmune hemolytic anemia (AHA), thalassemia intermedia, thalassemia major, sickle cell disease and Evans syndrome constitute the absolute indications for splenectomy and whenever the indication is established, the procedure should be performed laparoscopically, as the 'gold-standard' approach. Relative indications are: primarily unresponsiveness to medical therapy, disease relapse, splenomegaly, transfusion dependence, steroid dependency and intolerance or adverse side effects of steroid therapy (2, 6-27). In cases of concurrent symptomatic and asymptomatic non-complicated gallbladder lithiasis and benign hematological disorder, LS with concomitant laparoscopic cholecystectomy have been proposed as safe and feasible with acceptable operative time, conversion and transfusion rates and postoperative results $(6$, $17,19)$.

Current literature suggests that in patients who come under any of the previously mentioned indications and where surgeon's experience and adequate instrumentation are available, LS should be offered as the surgical treatment of choice $(6,10,11,21,22)$.

Absolute contraindications. These constitute: (i) uncorrected coagulopathy, (ii) severe comorbidities that highly increase the operative risk, and (iii) hematological malignancies not localized only in the spleen $(8,28,29)$.

Relative contraindications. A low platelet count $\left(<10 \times 10^{9} / 1\right)$ should no longer be considered as an absolute contraindication. Current literature states that the constant increased experience for the operation, as well as advances in laparoscopic techniques and instruments, have made it possible to operate on patients with low platelet counts safely and effectively (9).

LS should be performed with caution in cases of massive splenomegaly, which is defined either as a maximum spleen diameter greater than $25 \mathrm{~cm}$, or as an estimated spleen volume exceeding 1,000 $\mathrm{ml}$. Under these circumstances, LS is correlated with higher conversion rate and intra- and postoperative complications $(6,10,11,21,22)$. The procedure is technically demanding due to the limited abdominal working space, with an increased risk of bleeding and difficulty retrieving the spleen $(6,10,11,21,22)$. If LS is chosen, it can be performed using the same surgical technique, providing that the ports are placed more caudally on the abdominal wall, directly related to the lower pole of the spleen (30). For these patients, hand-assisted LS has been proposed $(11,20,31,32)$ as an effective, safe and feasible alternative. Analyzing the feasibility of LS in cases of massive splenomegaly (spleen weight $>2000 \mathrm{~g}$ ) in patients with benign hematological disorder, Al-Mulhim (7) concluded that although LS was feasible in $90 \%$ of patients, the condition was significantly associated with prolonged operative time, more blood loss, increased postoperative morbidity, longer time to liquid diet and prolonged postoperative hospital stay. Splenic weight above a cut-off value of $1311.5 \mathrm{~g}$ has been proposed to be associated with higher risk of conversion and transfusion and has also been found to be a significant independent risk factor for portal and splenic vein thrombosis (P/SVT) after LS (23).

Although the European Association for Endoscopic Surgery guidelines consider portal hypertension as an absolute contraindication for LS (33), several publications since then reported on the safety of the method in patients with cirrhosis and portal hypertension (24, 34-38).

With the progressive extension of technical feasibility, morbid obesity (body mass index; BMI $>35 \mathrm{~kg} / \mathrm{m}^{2}$ ) is no longer considered as an absolute contraindication for LS, although unquestionably difficulties remain due to limited intra-abdominal working space and poor viewing (39).

The pre-existing P/SVT is also a matter of debate since literature on adults is sparse. If we evaluated the literature on children with hematological disorders, we could state that splenectomy is indicated in cases of persistent abdominal pain, splenic abscesses, splenic infarct, hemorrhage, pseudocyst formation and rupture of the spleen $(37,38,40)$. Patrono et al. reported successful and effective LS following splenic artery embolization in an adult patient with chronic pancreatitis-related splenic vein thrombosis causing leftsided portal hypertension (41).

Finally, the higher cost of LS compared to OS could be considered as a relative contraindication for $\operatorname{LS}(42,43)$. However, a recent report disclosed that the hospital cost for LS was similar to the cost of OS $(2607 \pm 68.78$ US\$ for LS vs. $2601 \pm 60.13$ US\$ for OS) (13).

Preoperative workup. Preoperative workup for patients who are undergoing LS, requires a multidisciplinary approach. The need for blood and platelet transfusion, corticosteroid, plasmapheresis and gammaglobulin should be undertaken in conjunction with the patient's hematologists. Spleen size, spleen volume and identification of accessory spleens should be obtained with preoperative ultrasound and computed 
tomography $(10,11,13,20)$. Triple vaccination (Hemophilus influenza, Pneumococcus pneumoniae and Meningococcus) should be administered to all patients at least 2 weeks before surgery $(10,11)$. Patients taking corticosteroids should be given steroids parenterally during the perioperative period $(11,13)$. Antibiotic prophylaxis should be commenced at the time of induction to anesthesia and continued postoperatively for at least $24 \mathrm{~h}(7,10,11)$. All patients should have compression stockings $(10,11,20)$, while several authors suggest low-dose subcutaneous unfractionated heparin prophylaxis administration before LS, due to the increased risk of thromboembolic events correlated to the disorganization of coagulation and clotting homeostasis after splenectomy $(10,13,20)$.

Operative technique. For most authors, placement of the patient in the right lateral semi-decubitus position, with the table tilted in a slight reverse Trendelenburg position and flexed $30^{\circ}$ to open the space between the left iliac crest and the left costal margin, constitutes the preferable approach $(7$, $9-11,13,19,20,23,44)$. Open insertion of a $10-12 \mathrm{~mm}$ blunt-tipped trocar between the umbilicus and left costal margin is used to enter the abdomen, pneumoperitoneum is established and maintained at $12-16 \mathrm{mmHg}$, while two or three additional 5-10 $\mathrm{mm}$ ports are placed under direct vision along the costal margin (13).

Most authors also agree that the ideal number of trocars is four rather than three, since the fourth trocar can be helpful in spleen retraction and exposure of anatomical structures $(3,7,10,13,19,20,23,45-49)$.

Most authors prefer the lateral approach for spleen mobilization $(7,9,10,14,20)$. Almost all of them agree that the division of the gastrosplenic ligament and the short gastric vessels can be safely performed using an ultrasonic scalpel, while Al-Mulhim advocates the use of Ligaclips for the ligation of short gastric vessels greater than $4 \mathrm{~mm}$ in diameter (7).

Similarly, almost authors agree that the splenic vascular hilum can be safely divided by using a laparoscopic linear cutting stapler with vascular staples, assuming that the pancreatic tail has been isolated, in order to reduce the risk of pancreatic injury $(6,9,10,13,19-22)$. However, several modifications have been proposed. Corcione $e t$ al. suggested that the splenic artery should be identified and dissected free from the upper border of the pancreatic tail and clipped approximately $2 \mathrm{~cm}$ from the splenic hilum in order to reduce blood supply to the organ and to reduce its volume (10). Vecchio et al. suggested double clipping of the splenic artery prior to splenic vascular hilum division $(21,22)$. Li et $a l$. preferred to ligate and divide the splenic pedicle under direct vision, using traditional surgical instruments, through a 5-cm left subcostal incision, unifying two trocars holes (13). Zhou et al. used monopolar electrocautery for pedicle division suggesting the method as equally safe and effective, but also cost-effective compared to the endostapler and ultrasonic shear methods (42).

Several options are available for the retrieval of the specimen. Tran et al. preferred to place the spleen in a retrieval bag and to morcellate it prior to its removal through the largest port, while in patients with splenomegaly, the hand-assisted technique through a 7-8 $\mathrm{cm}$ supraumbilical midline incision was preferred (9). Suction drain was placed if pancreatic injury was suspected. Chen $e t$ al. captured the spleen in an extraction bag, morcellated it with ring forceps and removed it through the left $10-12 \mathrm{~mm}$ orifice (9). A drain tube was routinely placed in all patients. Marte et al. suggested that in cases of known or suspected malignancy, the spleen should be retrieved through a Pfannenstiel incision (14). A drain tube was left in all patients for 2 days. Li et al. withdrew the spleen through a small subcostal incision (13).

Lateral versus anterior approach. In general, a lateral approach provides better exposure of the splenic hilum and the pancreatic tail because the abdominal viscera are retracted away from the upper-left quadrant by gravity, allowing easier dissection of the splenic hilar structures and greater vascular control $(50,51)$. Other authors maintain that the lateral approach results in reduction of the number of trocars needed, shorter operative time, less intraoperative blood loss, lower conversion rate and shorter postoperative hospital stay $(10,52)$.

Corcione et al. concluded that a lateral approach was associated with shorter operative time (60 vs. $80 \mathrm{~min})$, less blood loss (30vs. $110 \mathrm{ml})$, no conversion (0vs. $2.2 \%)$, fewer postoperative complications $(4.8 \%$ vs. $31.5 \%)$, shorter hospital stay (3.1 vs. 5.2 days), less postoperative pain, only $1 \%$ fluid collection and no subphrenic abscesses formation, compared to the anterior approach (10).

Operative time. Depending on each study's methodology, the mean operative time was reported as being between 75 and 162 min, $(6,7,9,10,13,14,25,44)$, the mean operative time between 150 and $165 \mathrm{~min}(17,19)$ and the median operative time between 109 and $144 \min (18,20)$. However, splenomegaly (7), low platelet count (9), anterior approach (10), indications other than immune thrombocytopenic purpura (ITP) $(18,20)$ and concomitant laparoscopic cholecystectomy $(18,20)$, significantly prolonged the operative time.

Blood loss and requirements for transfusion. LS can be performed with minimal blood loss (mean 36-60 ml) $(6,13$, $17,19,25)$ and significantly less blood loss compared to OS (14). In the study of Vecchio et al., platelet transfusion was occasionally required (1 out of 12 patients) (6); in other studies, the need for packed erythrocyte transfusion was rare 
$(9,10)$, while intraoperative blood loss of more than $600 \mathrm{ml}$ (9), as well as the anterior approach (10), almost always lead to packed erythrocyte transfusion.

Conversion rate. Encountering the hand-assisted technique as a modification of LS, literature reports a very low conversion rate to OS, varying between 0 and $4 \%(6,7,9$, $10,14,17,19)$. In order of frequency, intraoperative bleeding $(9,10,14)$, splenomegaly $(11,17)$, anterior approach $(10)$ and surgeon's inexperience (10) constitute the main predisposing factors for conversion.

Postoperative course. The postoperative complications rate varied from $0 \%$ to $35.7 \%(6,9,10,14,18,45-49)$. Postoperative complications include bleeding $(12,17)$, PVT $(12,19,21)$, subphrenic abscess formation $(13,21)$, intestinal ischemia (40), pancreatic leakage (9), wound infections and respiratory complications (13). The reoperation rates varied from $0 \%$ to $6.7 \%(6-14,17,18,20,25,27,35,36,53)$.

Mortality rates varied from $0 \%$ to $3.9 \%$. $(2,3,6,9-12,18$, 21, 27, 29, 31, 35, 38, 41, 44-49, 51, 54-59). Gonzalez-Porras et al. reported two deaths after LS. One patient in the elderly group died due to severe intraoperative bleeding, while one patient in the young group died from a severe infection after surgery, although it remained unclear whether it was overwhelming post-splenectomy infection (OPSI) (12).

The postoperative hospital stay varied from 1 to 25 days, mainly related to the performance or not of concurrent laparoscopic cholecystectomy, the age of the patient (longer for elderly than for young patients) (12) and the development or not of postoperative complications $(6,9,12,17,19-22$, $53,59)$.

Other postoperative complications. P/SVT constitutes a potentially lethal complication following LS. The most recent reports addressed an incidence ranging from $0 \%(6$, 17 ) to $22.5 \%$ (20). Massive splenomegaly and splenic weight above a cut-off value of $1311.5 \mathrm{~g}$ were found to be significant independent risk factors for P/SVT after LS (23).

Tran et al. evaluated the incidence of P/SVT after LS performing surveillance duplex ultrasonography 1 week and 1 month postoperatively. The overall incidence of P/SVT was $22.5 \%$ (9 out of 40 patients), while the 1-week incidence was $20 \%$. Ultrasound was diagnostic in $87.5 \%$, while only one patient had mild symptoms such as fever and diarrhea (20). After anti-coagulation, subsequent ultrasound showed resolution or improvement in all patients. Conclusively, the high incidence of P/SVT following LS, justifies ultrasonographic screening on the seventh postoperative day.

Mohamad et al. showed that LS (as open splenectomy; OS) is correlated with life-threatening venous thromboembolic events in cases of patients with ITP if prophylactic anticoagulants are not administered (15).
Patients at risk are those who also have an exponential rise of the platelet count, although factors other than the platelet count may contribute in OS. Postsplenectomy, ITP should be considered as a thrombophilic condition and studies of additional measures to prevent such events are warranted.

OPSI is a medical emergency for which only prompt diagnosis and immediate treatment can reduce mortality (56). The mortality rate is $50-70 \%$, and most deaths occur within the first $24 \mathrm{~h}$ (60). To date, no data are available regarding whether LS is correlated with lower incidence of OPSI. The present literature review revealed only one documented case (14) of OPSI after LS.

Other minimally-invasive procedures. Li et al. compared laparoscopy-assisted small incision splenectomy to OS in patients with benign hematological disorders (13). There was no significant difference in the mean operating time and medical costs between the two groups, while blood loss, enterokinesia time, off-bed activity time, hospitalization time, and incidence of complications, were significant in the laparoscopic group.

Monclova et al. compared LS $(n=15)$ to reduced port access splenectomy (RPAS) $(n=10)$ as well as to single-port access splenectomy (SPAS) $(n=8)$ for the treatment of patients mainly suffering from benign hematological disorders. Blood loss and morbidity was similar in the three groups, as well as the clinical outcomes in terms of complications, re-operation and duration of hospital stay. No patients were converted to OS in any group, but three patients required additional trocars to finish the SPAS. RPAS had an operative time comparable to that of LS and significantly shorter than the SPAS (16). The results of this unique study are insufficient to establish any evidence of superiority of RPAS and SPAS over LS, apart from the better postoperative comfort and cosmetic result.

Effect of $L S$ on disease response. Complete response is defined as the achievement and maintenance of a platelets count of at least $100 \times 10^{9} / 130$ days or longer after splenectomy in the absence of bleeding and without additional ITP treatment, except tapering of perioperative glucocorticoids; partial response is defined as any platelet count between 30 and $100 \times 10^{9} / 12$ months after surgery in the absence of bleeding or any treatment; no response is defined as any platelet count $<30 \times 10^{9} / 1$ or bleeding, while relapse of ITP is defined as the loss of complete response or response, or when medical treatment is required to maintain a safe platelet count (61).

Gonzalez-Porras et al. reported an overall $89 \%$ favorable response to both laparoscopic and open splenectomy. The favorable response was significantly less common in patients older than 65 years compared to younger ones (79\% vs. 92\%, $p=0.005)$, the probability of maintaining response for 14 
years after splenectomy was only $56 \%$ in the elderly group, thus the authors concluded that patients aged $\geq 65$ years experienced negative effects on safety and efficacy outcomes of splenectomy for ITP (12).

Chen et al. compared the surgical outcomes in two groups of patients with ITP and low platelet count who underwent LS with and without intraoperative platelet transfusion. A steady growth of the platelet count was observed within the first week after surgery, while at discharge, $89 \%$ of the patients had achieved complete response, $9 \%$ a response and $2 \%$ did not respond (9). Based on the above, the authors concluded that a very low platelet count should not be a contraindication for LS in patients with ITP and perioperative platelet transfusion may be unnecessary.

Patel et al. presented the effect of LS in patients suffering from ITP refractory to medical treatment and AHA. In the ITP group $(n=45), 91 \%$ of the patients had complete response within a median period of 51 days, $17 \%$ of them relapsed within a median period of 135 days, $49 \%$ of them completely responded after the relapse, thus an overall response rate of $82 \%$ was achieved. In the AHA group $(n=15), 93 \%$ of the patients had complete response within a median period of 172 days, $29 \%$ of them relapsed within a median period of 31 days, $93 \%$ of them completely responded after the relapse, thus an overall response rate of 93\% was reached (18).

Wu et al. evaluated the efficacy of LS in patients suffering from ITP with a preoperative platelet count of less than $20 \times 10^{9} / 1$. The clinical efficacy of the treatment was significant, with an overall response rate of $90 \%$ (24).

$\mathrm{Wu}$ et al. reported the feasibility and safety of LS in the treatment of patients suffering from ITP with a preoperative platelet count of less than $1 \times 10^{9} / 1$. The authors found that after the third postoperative day, the platelet count increased sharply to $226.7 \times 10^{9} / 1$ and all patients remained complete responders within a mean follow-up of 28 months (25).

Zheng et al. presented a 10-year experience of LS for cases of chronic ITP. Within a mean follow-up of 43.6 months, the overall initial and long-term response rates were reported as $89.0 \%$ and $80.3 \%$, respectively (27). Univariate analysis showed that the responders were younger, had responded to steroid therapy and had a significantly higher postoperative peak platelet count. However, multivariate logistic regression analysis identified postoperative peak platelet count as the only independent predictor of favorable response to $\mathrm{LS}$.

Vecchio et al. demonstrated an overall response rate of $90.9 \%$, with a higher increase in postoperative percentage platelet count in patients with a lower preoperative platelet count (62).

Tables I and II summarize the results of studies of LS for the treatment of benign hematological disorders from 2010 to date.

\section{Critical Evaluation}

Patients with benign hematological diseases such as ITP, AHA or HS are mainly treated with high-dose corticosteroid administration (63). However, splenectomy represents a frequent component in their management and should be reserved for patients with refractory, recurrent or chronic diseases for whom drug treatment fails (63).

Over the past two decades, minimally-invasive surgical approaches to splenectomy have been increasingly adopted. Technical considerations (feasibility), favorable postoperative course (safety), as well as achievement and maintenance of a favorable long-term response (effectiveness), should be taken into consideration prior to any definitive conclusion regarding the role of LS in hematological diseases in adults.

Literature reports that uncorrected coagulopathy, severe comorbidities which highly increase the operative risk, and hematological malignancies not localized only in the spleen are the only absolute contraindications for $\operatorname{LS}(8,28,29)$. Patients with any other condition should be considered as candidates for splenectomy and LS should be offered to them as the 'gold-standard' operation of choice. As LS became more mature and its indications gradually expanded, the method has displaced OS for almost all indications (33) in experienced surgeon's hands.

Ideally, all patients should preoperatively have undergone abdominal computed tomography scan for documentation of spleen size, spleen volume and identification of accessory spleens.

In the presence of a normal coagulation profile, a low platelet count should not preclude LS any longer (9, 24-27). In patients with massive splenomegaly and heavy spleens, LS should firstly be attempted $(7,14)$, keeping in mind that the ports should be placed more caudally on the abdominal wall directly related to the lower pole of the spleen (30), the modification of hand-assisted technique might prove extremely helpful, but despite these maneuvers, the conversion rate remains high. Placement of the patient in the right lateral semi-decubitus position, 4-trocar technique and lateral approach for spleen mobilization, constitute the preferable approach. Division of the gastrosplenic ligament and the short gastric vessels can be safely perform using an ultrasonic scalpel, while the splenic vascular hilum can be safely divided by using a laparoscopic linear cutting stapler with vascular staples $(9,10,13,19-22)$. However, any laparoscopic technique (e.g. clips, knots, individual dissection and clipping of the vessels at the splenic hilum) based on the surgeon's experience and dexterity, which further increases the safety for splenic artery ligation, can be applied and is acceptable. Morcellation of the spleen within a retrieval bag constitutes the preferable option for specimen retrieval.

Two meta-analyses unanimously concluded that LS is characterized by less blood loss, less requirements for 
in vivo 31 : 291-302 (2017)

Table I. Summary of the studies of laparoscopic splenectomy (LS) from 2010 to date: Design and conclusions.

\begin{tabular}{|c|c|c|c|c|c|c|}
\hline Author & $\begin{array}{c}\text { Year of } \\
\text { publication }\end{array}$ & $\begin{array}{l}\text { Study } \\
\text { design }\end{array}$ & $\begin{array}{l}\text { No. of } \\
\text { patients }\end{array}$ & Indication & $\begin{array}{l}\text { Operative } \\
\text { technique }\end{array}$ & Conclusion \\
\hline Sazaki et al. (19) & 2010 & Retrospective & $\begin{array}{c}9 \text { (All with } \\
\text { concurrent LC) }\end{array}$ & $\begin{array}{c}\text { HS } \\
\text { Splenic artery aneurysm } \\
\text { Hypersplenism } \\
\text { Evans syndrome }\end{array}$ & LA, 4 trocars & $\begin{array}{l}\text { Concomitant LS and LC are } \\
\text { safe and feasible procedures. }\end{array}$ \\
\hline Mohamed et al. (15) & 2010 & Retrospective & 21 & Chronic ITP & LA, 4 trocars & $\begin{array}{l}\text { Life-threatening venous } \\
\text { thromboembolic events are } \\
\text { serious complications after } \\
\text { LS and OS for ITP patients } \\
\text { if prophylactic anticoagulants } \\
\text { are not administered. }\end{array}$ \\
\hline Tran et al. (20) & 2010 & Prospective & 31 & $\begin{array}{c}\text { HS } \\
\text { ITP } \\
\text { Hypersplenism } \\
\text { AHA } \\
\text { Evans syndrome }\end{array}$ & LA, 4 trocars & $\begin{array}{l}\text { The 1-week incidence of } \\
\text { P/SVT after LS was } 20 \% \text {. } \\
\text { The high incidence justifies } \\
\text { ultrasonographic screening } \\
\text { on postoperative day } 7 . \\
\text { If asymptomatic P/SVT has } \\
\text { not developed at this time, } \\
\text { screening ultrasound at } \\
1 \text { month is not required. }\end{array}$ \\
\hline Nobili et al. (17) & 2011 & Retrospective & $\begin{array}{l}125 \text { (30 with } \\
\text { concurrent LC) }\end{array}$ & $\begin{array}{c}\text { ITP } \\
\text { HS } \\
\text { Thalassemia } \\
\text { Sickle cell disease }\end{array}$ & $\begin{array}{l}\text { LA, } 4 \text { or } \\
5 \text { trocars }\end{array}$ & $\begin{array}{l}\text { Concomitant LS and LC are } \\
\text { safe and feasible procedures. }\end{array}$ \\
\hline Chen et al. (9) & 2011 & Retrospective & 81 & ITP & LA, 4 trocars & $\begin{array}{c}\text { Very low platelet count } \\
\text { should not constitute } \\
\text { a contraindication for LS } \\
\text { in ITP patients. } \\
\text { Perioperative platelet } \\
\text { transfusion may be unnecessary }\end{array}$ \\
\hline Wu et al. (25) & 2011 & Retrospective & 10 & ITP & LA, 4 trocars & $\begin{array}{l}\text { LS is a feasible technique } \\
\text { in the treatment of ITP } \\
\text { patients with low platelet coun }\end{array}$ \\
\hline Zheng et al. (27) & 2011 & Retrospective & 154 & Chronic ITP & LA, 4 trocars & $\begin{array}{l}\text { LS is a safe and effective } \\
\text { treatment for chronic ITP. } \\
\text { Postoperative peak platelet } \\
\text { count may serve as a major } \\
\text { predictor of long-term response }\end{array}$ \\
\hline Zheng et al. (26) & 2012 & Retrospective & 58 & Chronic ITP & LA, 4 trocars & $\begin{array}{l}\text { Haptoglobin levels may serve } \\
\text { as a favorable predictor for } \\
\text { the long-term response to } \\
\text { splenectomy in ITP. }\end{array}$ \\
\hline Wu et al. (24) & 2012 & Retrospective & 30 & ITP & LA, 4 trocars & $\begin{array}{l}\text { LS without platelet transfusion } \\
\text { can be safely performed in } \\
\text { patients with platelet count } \\
\text { lower than } 20 \times 10^{9} / 1 \text {. }\end{array}$ \\
\hline Al-Mulhim (7) & 2012 & Retrospective & 81 & Sickle cell disease. & LA, 4 trocars & $\begin{array}{l}\text { Although LS was feasible } \\
\text { in } 90 \% \text { of patients with massive } \\
\text { splenomegaly }(>2,000 \mathrm{~g}) \text {, the } \\
\text { condition was statistically } \\
\text { significant associated to prolong } \\
\text { operative time, more blood } \\
\text { loss, increased postoperative } \\
\text { morbidity, longer time to } \\
\text { liquid diet and prolong } \\
\text { postoperative hospital stay. }\end{array}$ \\
\hline
\end{tabular}


Table I. Continued

\begin{tabular}{|c|c|c|c|c|c|c|}
\hline Author & $\begin{array}{c}\text { Year of } \\
\text { publication }\end{array}$ & $\begin{array}{l}\text { Study } \\
\text { design }\end{array}$ & $\begin{array}{l}\text { No. of } \\
\text { patients }\end{array}$ & Indication & $\begin{array}{l}\text { Operative } \\
\text { technique }\end{array}$ & Conclusion \\
\hline Patel et al. (18) & 2012 & Retrospective & 58 & $\begin{array}{c}\text { ITP } \\
\text { AHA }\end{array}$ & LA, 4 trocars & $\begin{array}{l}\text { LS for ITP and AHA has } \\
\text { favorable response rates } \\
\text { with low morbidity in cases } \\
\text { non-responding in } \\
\text { medical therapy. }\end{array}$ \\
\hline Corcione et al. (10) & 2012 & Retrospective & $\begin{array}{c}300 \text { (201 for } \\
\text { benign disease). }\end{array}$ & $\begin{array}{c}\text { ITP } \\
\text { HS } \\
\text { Thalassemia. }\end{array}$ & $\begin{array}{l}\mathrm{LA}, 4 \text { trocars } \\
\quad(\mathrm{n}=208)\end{array}$ & $\begin{array}{l}\text { LS with lateral approach } \\
\text { and the placement of four } \\
\text { trocars can be considered } \\
\text { the procedure of choice } \\
\text { for benign diseases } \\
\text { affecting the spleen. }\end{array}$ \\
\hline Fraser et al. (11) & 2012 & Retrospective & 48 & $\begin{array}{c}\text { ITP, Mixed ITP/TTP } \\
\text { HS } \\
\text { AHA } \\
\text { Hypersplenism }\end{array}$ & AA $(n=92)$ & $\begin{array}{c}\text { No significant differences } \\
\text { in operative time, } \\
\text { transfusion requirements, } \\
\text { morbidity rate and } \\
\text { mortality rate between } \\
\text { patients with benign and } \\
\text { malignant disease. }\end{array}$ \\
\hline Monclova et al. (16) & 2013 & $\begin{array}{c}\text { Prospective, } \\
\text { comparative, } \\
\text { nonrandomized }\end{array}$ & $\begin{array}{l}28 \text { Cases of } \\
\text { traditional and } \\
\text { alternative LS } \\
\text { approaches. }\end{array}$ & $\begin{array}{c}\text { ITP } \\
\text { AHA } \\
\text { HS } \\
4 \text { Cases of malignancies } \\
\text { were excluded. }\end{array}$ & & $\begin{array}{l}\text { RPAS has an operative time } \\
\text { comparable to the LS and } \\
\text { significantly shorter than } \\
\text { the SPAS. No patients were } \\
\text { converted to open surgery } \\
\text { in any group, but three } \\
\text { patients required additional } \\
\text { trocars to finish the SPAS. } \\
\text { RPAS is a good alternative } \\
\text { to LS and SPAS. Both } \\
\text { methods improve the cosmetic } \\
\text { results compared to LS. }\end{array}$ \\
\hline Li et al. (13) & 2013 & Retrospective & 60 & $\begin{array}{l}\text { ITP } \\
\text { HS }\end{array}$ & $\mathrm{LA}, 4$ trocars & $\begin{array}{l}\text { Blood loss, enterokinesia } \\
\text { time, off-bed activity time, } \\
\text { hospitalization time and } \\
\text { incidence of complications } \\
\text { in the LS group decreased } \\
\text { significantly compared to } \\
\text { the open splenectomy group. }\end{array}$ \\
\hline Marte et al. (14) & 2013 & Retrospective & 33 & $\begin{array}{c}\text { ITP } \\
\text { HS } \\
\text { Splenic artery aneurysm } \\
\text { Hypersplenism. }\end{array}$ & & $\begin{array}{l}\text { LS should be considered } \\
\text { as the preferential approach } \\
\text { in patients with benign } \\
\text { disease, splenomegaly, or } \\
\text { unusual cases. Massive } \\
\text { splenomegaly should be } \\
\text { considered as relative } \\
\text { contraindication to LS } \\
\text { even at experienced centers. }\end{array}$ \\
\hline Wang et al. (23) & 2014 & Retrospective & 25 & Thalassemia major & RPAS $(n=10)$ & $\begin{array}{l}\text { LS group had statistically } \\
\text { significant: increased } \\
\text { operative time, less blood } \\
\text { loss and decreased postoperative } \\
\text { stay. LS group was susceptible } \\
\text { to PVT (splenic weight can } \\
\text { be used as a predictor). }\end{array}$ \\
\hline Vecchio et al. (6) & 2014 & Retrospective & 12 & $\begin{array}{c}\text { ITP } \\
\text { HS } \\
\text { Thalassemia intermedia }\end{array}$ & SPAS $(n=8)$ & $\begin{array}{l}\text { Concurrent LS with LC. } \\
\text { Feasible with low blood } \\
\text { loss and acceptable } \\
\text { operative time. }\end{array}$ \\
\hline
\end{tabular}


Table I. Continued

\begin{tabular}{|c|c|c|c|c|c|c|}
\hline Author & $\begin{array}{c}\text { Year of } \\
\text { publication }\end{array}$ & $\begin{array}{l}\text { Study } \\
\text { design }\end{array}$ & $\begin{array}{l}\text { No. of } \\
\text { patients }\end{array}$ & Indication & $\begin{array}{l}\text { Operative } \\
\text { technique }\end{array}$ & Conclusion \\
\hline $\begin{array}{l}\text { Gonzalez-Porras } \\
\text { et al. (12) }\end{array}$ & 2014 & Retrospective & 118 & ITP & $\operatorname{LS}(n=15)$ & $\begin{array}{l}\text { A favorable response following } \\
\text { LS was significantly less } \\
\text { common in elderly than } \\
\text { in young people. }\end{array}$ \\
\hline Pardhan et al. (59) & 2014 & Retrospective & 4 & ITP & & $\begin{array}{l}\text { Splenectomy is a safe } \\
\text { treatment option especially in } \\
\text { patients who succumb } \\
\text { to adverse effects of } \\
\text { medical therapy. }\end{array}$ \\
\hline Rijcken et al. (47) & 2014 & Retrospective & 72 & ITP & LA, 4 trocars & $\begin{array}{l}\text { Perioperative platelet counts } \\
\text { are predictive factors } \\
\text { of long term response. }\end{array}$ \\
\hline Cai et al. (46) & 2014 & Retrospective & 88 & ITP & LA, 4 trocars & $\begin{array}{l}\text { It is safe and feasible to } \\
\text { perform LS in ITP patients with } \\
\text { platelet count less than } 10 \times 10^{9} / 1 \text {, } \\
\text { without platelet transfusion. }\end{array}$ \\
\hline Navez et al. (45) & 2015 & Retrospective & 81 & ITP & & $\begin{array}{c}\text { Age and pre-operative platelet } \\
\text { count were significant predictors } \\
\text { of recurrence-free survival }\end{array}$ \\
\hline Leo et al. (44) & 2015 & Retrospective & 2 & ITP & LA, 4 trocars & $\begin{array}{l}\text { The laparoscopic accessory } \\
\text { splenectomy should be } \\
\text { considered the first- } \\
\text { choice approach. }\end{array}$ \\
\hline Vecchio et al. (62) & 2015 & Retrospective & 20 & ITP & & $\begin{array}{l}\text { A higher increase of } \\
\text { postoperative percent platelet } \\
\text { count may be predicted in } \\
\text { patients with a low } \\
\text { preoperative platelet count. }\end{array}$ \\
\hline Antel et al. (49) & 2015 & Retrospective & 43 & $\begin{array}{l}\text { ITP in patients } \\
\text { with HIV }\end{array}$ & LA, 4 trocars & $\begin{array}{l}\text { LS achieved a complete } \\
\text { response of } 83 \% \text { and response } \\
\text { was sustained for at least } 1 \text { year }\end{array}$ \\
\hline $\mathrm{Xu}$ et al. (48) & 2016 & Retrospective & 114 & ITP & LA, 4 trocars & $\begin{array}{c}\text { The } 140 \text {-month response } \\
\text { rate to LS was } 68 \%\end{array}$ \\
\hline
\end{tabular}

TTP: Thrombotic thrombopenic purpura, HS: hereditary spherocytosis, ITP: immune thrombocytopenic purpura, AHA: autoimmune hemolytic anemia, As above: anterior approach, LA: laparoscopic approach, LC: laparoscopic cholecystectomy, RPAS: reduced port access splenectomy, SPAS: single port access splenectomy, PVT: portal vein thrombosis, P/SVT: portal/splenic vein thrombosis, HIV: human immunodeficiency virus.

transfusion, lower morbidity rate, shorter postoperative hospital stay, better cosmetic result, equivalent mortality, but prolonged operative time, compared to OS, even in cases of massive splenomegaly $(8,64)$. Postoperative bleeding and pulmonary complications constituted the majority of severe complications, whereas incision complications were the most common minor complications. The proposed increased cost of LS $(42,43)$ does not seem to be confirmed by recent studies (13), probably because the cost of laparoscopic equipment is balanced out by the shorter postoperative hospital stay.

Although the true incidence of P/SVT is unknown because it remains mainly asymptomatic, the more extensive use of radiological imaging now seems to indicate that it probably occurs more often than earlier thought. LS might increase the risk of P/SVT because it reduces the blood flow in the portal system due to the pneumoperitoneum; however, on the other hand, it seems to be associated with fewer postoperative modifications of coagulation parameters and of fibrinolytic postoperative pathways than OS, thus preventing P/SVT itself $(6,17,19,21-23,64)$. Because P/SVT constitutes a potentially lethal complication following LS, literature shows that patients with myeloproliferative disorders, hemolytic diseases and marked splenomegaly are at higher risk for its development, thus ultrasonographic screening as routine on the seventh postoperative day is now justified (65).

Following LS for ITP, many patients may experience an exponential rise of their platelet count. In these cases, ITP should be considered as a thrombophilic condition and prophylactic anticoagulants should be administered (15). 
Table II. Summary of the studies of laparoscopic splenectomy from 2010 to date: Complications and reoperation.

\begin{tabular}{|c|c|c|c|c|}
\hline Author & Postoperative complications & $\begin{array}{l}\text { 90-Day } \\
\text { mortality rate }\end{array}$ & $\begin{array}{l}\text { Morbidity } \\
\text { rate }\end{array}$ & $\begin{array}{l}\text { Reoperation } \\
\text { rate }\end{array}$ \\
\hline Sazaki et al. (19) & PVT, bleeding & $0 \%$ & $22 \%$ & $0 \%$ \\
\hline Mohamed et al. (15) & PE, DVT & $0 \%$ & $9.5 \%$ & $0 \%$ \\
\hline Tran et al. (20) & $\begin{array}{l}\text { Splenic bed collection, peripancreatic fluid collections, } \\
\text { bleeding from the splenic artery stump, symptomatic PVT }\end{array}$ & $0 \%$ & $6.25 \%$ & $0 \%$ \\
\hline Nobili et al. (17) & Hemoperitoneum & $0 \%$ & $10 \%$ & $0 \%$ \\
\hline Chen et al. (9) & Bleeding, pneumonia, subphrenic fluid collection, left pleural effusion & $0 \%$ & $11 \%$ & $0 \%$ \\
\hline Wu et al. (25) & Subphrenic hematoma, bleeding & $0 \%$ & $0 \%$ & $0 \%$ \\
\hline Zheng et al. (27) & Subphrenic abscess, bleeding & $0.6 \%$ & $8.4 \%$ & $0 \%$ \\
\hline Zheng et al. (26) & $\mathrm{N} / \mathrm{A}$ & $\mathrm{N} / \mathrm{A}$ & N/A & N/A \\
\hline Wu et al. (24) & Subphrenic hematoma, bleeding & $0 \%$ & $0 \%$ & $0 \%$ \\
\hline Al-Mulhim (7) & Acute chest syndrome, left subphrenic hematoma, left pleural effusion & $0 \%$ & $8.4 \%$ & $0 \%$ \\
\hline Patel et al. (18) & PE, DVT, pneumonia, MI & $0 \%$ & $10 \%$ & $0 \%$ \\
\hline Corcione et al. (10) & $\begin{array}{l}\text { Fluid collections in the splenic fossa, subphrenic } \\
\text { abscesses, bleeding, intestinal ischemia }\end{array}$ & $0.3 \%$ & $13 \%$ & $1 \%$ \\
\hline Fraser et al. (11) & PVT, sepsis, bleeding, intestinal ischemia & $3.9 \%$ & $21.1 \%$ & N/A \\
\hline Monclova et al. (16) & $\begin{array}{l}\text { Bleeding from a vessel of the greater omentum, } \\
\text { subphrenic fluid collection, pancreatic fistula. }\end{array}$ & $0 \%$ & $15.6 \%$ & $3 \%$ \\
\hline Li et al. (13) & Wound complications, sepsis, subhepatic abscess, respiratory complications & $0 \%$ & $6.67 \%$ & $0 \%$ \\
\hline Marte et al. (14) & Bleeding, OPSI & $2.08 \%$ & $8.8-35.7 \%$ & $0 \%$ \\
\hline Wang et al. (23) & Bleeding, PVT & $0 \%$ & $6.9 \%$ & $6.9 \%$ \\
\hline Vecchio et al. (6) & $\begin{array}{l}\text { Conversion to open surgery was required in one patient because of } \\
\text { lack of anatomic definition of Calot triangle's structures. }\end{array}$ & $0 \%$ & $0 \%$ & $0 \%$ \\
\hline Gonzalez-Porras et al. (12) & Infection, subphrenic abscess, thrombotic events, bleeding & $0.9 \%$ & $25.4 \%$ & N/A \\
\hline Pardhan et al. (59) & Atelectasis & $0 \%$ & $25 \%$ & N/A \\
\hline \multicolumn{5}{|l|}{ Rijcken et al. (47) } \\
\hline Cai et al. (46) & Bleeding, pancreatic fistula, PVT & $0 \%$ & $11.4 \%$ & $0 \%$ \\
\hline Navez et al. (45) & N/A & N/A & N/A & N/A \\
\hline Leo et al. (44) & None & $0 \%$ & $0 \%$ & $0 \%$ \\
\hline Vecchio et al. (62) & $\mathrm{N} / \mathrm{A}$ & $0 \%$ & N/A & N/A \\
\hline Antel et al. (49) & Bleeding, PVT, intra-abdominal abscess & $1.38 \%$ & N/A & $16.3 \%$ \\
\hline $\mathrm{Xu}$ et al. (48) & PVT, pneumonia, pancreatic fistula & $0 \%$ & $7 \%$ & N/A \\
\hline
\end{tabular}

PVT: Portal vein thrombosis, N/A: not available, MI: myocardial infarction, DVT: deep vein thrombosis, PE: pulmonary embolism, OPSI: overwhelming post-splenectomy infection.

The indications for splenectomy most frequently associated with a risk of infection were thalassemia major, sickle-cell anemia, HS, and ITP. The use of antibiotics for the prevention of post-splenectomy sepsis is not evidencebased. The actual effectiveness of antibiotics is unknown and there is no agreement on how long such drugs should be taken or which subgroups to treat, especially when factors such as poor compliance and possibility of favoring the development of resistant bacterial strains in the long term are taken into account $(54,58)$. In adults, guidelines recommend prophylaxis with $250-500 \mathrm{mg}$ per day of amoxicillin or 500 $\mathrm{mg}$ per day phenoxymethylpenicillin (58). Although there is no consensus on the duration of treatment, the only available guidelines (British) propose life-long treatment with regards to the persistent risk of sepsis (54). Long-term treatment is recommended in patients with concomitant hematological diseases or an impaired immune system (54). Improvement of patients' education about their asplenic or hyposplenic status and increased healthcare worker awareness about the potential fulminant progression of infections in splenectomized patients, represent mandatory strategies for preventing and managing post-splenectomy sepsis and OPSI.

Splenectomy is a common therapy for adults with ITP. The first published systematic review by Kojouri et al. in 2004 , disclosed a $66 \%$ complete response within a followup period of 1 to 153 months (66). The next systematic review by Mikhael et al. in 2009, revealed short-term surgical non-response rate of $8.2 \%$, long-term relapse rate of approximately 44/1,000 patients/year and an approximate failure rate of $28 \%$ at 5 years for all patients undergoing splenectomy (4). Studies with shorter durations of follow-up had significantly higher relapse rates than studies with longer follow-up. It was concluded that splenectomy may have higher initial relapse rates in the first 2 years after surgery, 
but the rate may decline over time. The most recent studies $(9,12,18,24-27)$, disclosed a short-term response rate of about $90 \%$ and long-term response rate higher than $80 \%$, or even $100 \%$. However, the probability of maintaining response for 14 years after splenectomy was only $56 \%$ in elderly patients, thus patients aged $\geq 65$ years experienced negative effects on safety and efficacy outcomes of splenectomy for ITP (12).

\section{Conclusion}

Almost 25 years since its introduction, LS should now constitute the 'gold standard' surgical treatment for hematological disorders in adults requiring splenectomy. Uncorrected coagulopathy, severe comorbidities that highly increase the operative risk, and hematological malignancies not localized only in the spleen, represent the only absolute contraindications for the procedure.

In all other benign and malignant hematological diseases, LS should be offered as the first surgical option. Although specific circumstances and conditions increase the conversion rate, the laparoscopic approach should be attempted first.

The right lateral semi-decubitus position of the patient, the 4-trocar technique and the lateral approach for spleen mobilization, constitute the preferable approach, increasing the feasibility of the method.

Antibiotic administration for at least $24 \mathrm{~h}$, thromboprophylaxis measurements, postoperative prophylactic anticoagulant administration (if required) and ultrasonographic screening for P/SVT on the seventh postoperative day increase the safety of the method, ensuring an excellent short-term outcome.

Especially for ITP, the $66 \%$ complete response rate reported in 2004 increased to $72 \%$ in 2009 , while the most recent (2010-2016) published results disclosed short-term response rate of about $90 \%$ and long-term response rate higher than $80 \%$ in patients younger than 65 years-old, documenting the effectiveness of the LS method.

\section{Supportive Foundations}

None.

\section{Conflicts of Interest}

Authors have no conflicts of interest.

\section{References}

1 Delaitre B and Maignien B: Splenectomy by the laparoscopic approach. Report of a case. Presse Med 20(44): 2263, 1991.

2 Sotomayor-Ramirez RK: Efficacy and safety of laparoscopic splenectomy: Review of 14 adult cases using the lateral approach. Bol Asoc Med P R 101(2): 43-49, 2009.
3 Delaitre B, Blezel E, Samama G, Barrat C, Gossot D, Bresler L, Meyer C, Heyd B, Collet D and Champault G: Laparoscopic splenectomy for idiopathic thrombocytopenic purpura. Surg Laparosc Endosc Percutan Tech 12(6): 412-419, 2002.

4 Mikhael J, Northridge K, Lindquist K, Kessler C, Deuson R and Danese M: Short-term and long-term failure of laparoscopic splenectomy in adult immune thrombocytopenic purpura patients: A systematic review. Am J Hematol 84(11): 743-748, 2009.

5 Moher D, Liberati A, Tetzlaff J, Altman DG and Group P: Preferred reporting items for systematic reviews and metaanalyses: The prisma statement. BMJ 339: b2535, 2009.

6 Vecchio R, Intagliata E, Marchese S, La Corte F, Cacciola RR and Cacciola E: Laparoscopic splenectomy coupled with laparoscopic cholecystectomy. JSLS 18(2): 252-257, 2014.

7 Al-Mulhim AS: Laparoscopic splenectomy for massive splenomegaly in benign hematological diseases. Surg Endosc 26(11): 3186-3189, 2012.

8 Bai YN, Jiang $\mathrm{H}$ and Prasoon P: A meta-analysis of perioperative outcomes of laparoscopic splenectomy for hematological disorders. World J Surg 36(10): 2349-2358, 2012.

9 Chen X, Peng B, Cai Y, Zhou J, Wang Y, Wu Z and Chen S: Laparoscopic splenectomy for patients with immune thrombocytopenia and very low platelet count: Is platelet transfusion necessary? J Surg Res 170(2): e225-232, 2011.

10 Corcione F, Pirozzi F, Aragiusto G, Galante F and Sciuto A: Laparoscopic splenectomy: Experience of a single center in a series of 300 cases. Surg Endosc 26(10): 2870-2876, 2012.

11 Fraser SA, Bergman S and Garzon J: Laparoscopic splenectomy: Learning curve comparison between benign and malignant disease. Surg Innov 19(1): 27-32, 2012.

12 Gonzalez-Porras JR, Escalante F, Pardal E, Sierra M, GarciaFrade LJ, Redondo S, Arefi M, Aguilar C, Ortega F, de Cabo E, Fisac RM, Sanz O, Esteban C, Alberca I, Sanchez-Barba M, Santos MT, Fernandez A, Gonzalez-Lopez TJ and Grupo de Trombosis y Hemostasia de Castilla y L: Safety and efficacy of splenectomy in over 65-yrs-old patients with immune thrombocytopenia. Eur J Haematol 91(3): 236-241, 2013.

13 Li B, Liu J, Shangguan Y, Liu B and Qi Y: Laparoscopy-assisted small incision splenectomy and open splenectomy in the treatment of hematologic diseases: A single-institution comparative experience. Surg Laparosc Endosc Percutan Tech 23(3): 309-311, 2013.

14 Marte G, Scuderi V, Rocca A, Surfaro G, Migliaccio C and Ceriello A: Laparoscopic splenectomy: A single-center experience. Unusual cases and expanded inclusion criteria for laparoscopic approach. Updates Surg 65(2): 115-119, 2013.

15 Mohamed SY, Abdel-Nabi I, Inam A, Bakr M, El Tayeb K, Saleh AJ, Alzahrani $\mathrm{H}$ and Abdu SH: Systemic thromboembolic complications after laparoscopic splenectomy for idiopathic thrombocytopenic purpura in comparison to open surgery in the absence of anticoagulant prophylaxis. Hematol Oncol Stem Cell Ther 3(2): 71-77, 2010.

16 Monclova JL, Targarona EM, Vidal P, Peraza Y, Garcia F, Otero $\mathrm{CR}$, Pallares L, Balague $\mathrm{C}$ and Trias M: Single incision versus reduced port splenectomy--searching for the best alternative to conventional laparoscopic splenectomy. Surg Endosc 27(3): 895902, 2013.

17 Nobili C, Romano F, Ciravegna AL, Garancini M, Degrate L, Uggeri $\mathrm{F}$ and Uggeri F: Consecutive concomitant laparoscopic 
splenectomy and cholecystectomy: An italian experience of 30 patients and proposition of a technique. J Laparoendosc Adv Surg Tech A 21(4): 313-317, 2011.

18 Patel NY, Chilsen AM, Mathiason MA, Kallies KJ and Bottner WA: Outcomes and complications after splenectomy for hematologic disorders. Am J Surg 204(6): 1014-1019; discussion 1019-1020, 2012.

19 Sasaki A, Nitta H, Otuska K, Kimura Y, Obuchi $\mathrm{T}$ and Wakabayashi G: Concomitant laparoscopic splenectomy and cholecystectomy. Surg Laparosc Endosc Percutan Tech 20(2): 66-68, 2010.

20 Tran T, Demyttenaere SV, Polyhronopoulos G, Seguin C, Artho GP, Kaneva P, Fried GM and Feldman LS: Recommended timing for surveillance ultrasonography to diagnose portal splenic vein thrombosis after laparoscopic splenectomy. Surg Endosc 24(7): 1670-1678, 2010.

21 Vecchio R, Cacciola E, Cacciola RR, Marchese S and Intagliata E: Portal vein thrombosis after laparoscopic and open splenectomy. J Laparoendosc Adv Surg Tech A 21(1): 71-75, 2011.

22 Vecchio R, Marchese S, Swehli E and Intagliata E: Splenic hilum management during laparoscopic splenectomy. J Laparoendosc Adv Surg Tech A 21(8): 717-720, 2011.

23 Wang M, Zhang M, Li J, Zhou J, Wu Z and Peng B: Risk factors of portal vein thrombosis in patients with beta thalassemia major after splenectomy: Laparoscopic versus open procedure. Hepatogastroenterology 61(129): 48-54, 2014.

24 Wu Z, Zhou J, Li J, Zhu Y and Peng B: The feasibility of laparoscopic splenectomy for ITP patients without preoperative platelet transfusion. Hepatogastroenterology 59(113): 81-85, 2012.

$25 \mathrm{Wu}$ Z, Zhou J, Pankaj P and Peng B: Laparoscopic splenectomy for immune thrombocytopenia (ITP) patients with platelet counts lower than 1×109/1. Int J Hematol 94(6): 533-538, 2011.

26 Zheng CX, Ji ZQ, Zhang LJ, Wen Q, Chen LH, Yu JF and Zheng D: Proteomics-based identification of haptoglobin as a favourable serum biomarker for predicting long-term response to splenectomy in patients with primary immune thrombocytopenia. J Transl Med 10: 208, 2012.

27 Zheng CX, Zheng D, Chen LH, Yu JF and Wu ZM: Laparoscopic splenectomy for immune thrombocytopenic purpura at a teaching institution. Chin Med J (Engl) 124(8): 1175-1180, 2011.

28 Heniford BT, Matthews BD, Answini GA and Walsh RM: Laparoscopic splenectomy for malignant diseases. Semin Laparosc Surg 7(2): 93-100, 2000.

29 Casaccia M, Torelli P, Squarcia S, Sormani MP, Savelli A, Troilo B, Santori G and Valente U: Laparoscopic splenectomy for hematologic diseases: A preliminary analysis performed on the Italian Registry of Laparoscopic Surgery of the Spleen (IRLSS). Surg Endosc 20(8): 1214-1220, 2006.

30 Casaccia M, Torelli P, Pasa A, Sormani MP, Rossi E and Centers I: Putative predictive parameters for the outcome of laparoscopic splenectomy: A multicenter analysis performed on the Italian Registry of Laparoscopic Surgery of the Spleen. Ann Surg 251(2): 287-291, 2010

31 Barbaros U, Dinccag A, Sumer A, Vecchio R, Rusello D, Randazzo V, Issever $\mathrm{H}$ and Avci C: Prospective randomized comparison of clinical results between hand-assisted laparoscopic and open splenectomies. Surg Endosc 24(1): 25-32, 2010 .
32 Swanson TW, Meneghetti AT, Sampath S, Connors JM and Panton ON: Hand-assisted laparoscopic splenectomy versus open splenectomy for massive splenomegaly: 20-year experience at a Canadian centre. Can J Surg 54(3): 189-193, 2011.

33 Habermalz B, Sauerland S, Decker G, Delaitre B, Gigot JF, Leandros E, Lechner K, Rhodes M, Silecchia G, Szold A, Targarona E, Torelli P and Neugebauer E: Laparoscopic splenectomy: The clinical practice guidelines of the European Association for Endoscopic Surgery (EAES). Surg Endosc 22(4): 821-848, 2008.

34 Bo W, He-Shui W, Guo-Bin W and Kai-Xiong T: Laparoscopy splenectomy for massive splenomegaly. J Invest Surg 26(3): 154-157, 2013.

35 Zhan XL, Ji Y and Wang YD: Laparoscopic splenectomy for hypersplenism secondary to liver cirrhosis and portal hypertension. World J Gastroenterol 20(19): 5794-5800, 2014.

36 Zhu JH, Wang YD, Ye ZY, Zhao T, Zhu YW, Xie ZJ and Liu JM: Laparoscopic versus open splenectomy for hypersplenism secondary to liver cirrhosis. Surg Laparosc Endosc Percutan Tech 19(3): 258-262, 2009.

37 Kawanaka H, Akahoshi T, Kinjo N, Iguchi T, Ninomiya M, Yamashita YI, Ikegami T, Yoshizumi T, Shirabe K and Maehara Y: Effect of laparoscopic splenectomy on portal haemodynamics in patients with liver cirrhosis and portal hypertension. Br J Surg 101(12): 1585-1593, 2014.

38 Zhou J, Wu Z, Pankaj P and Peng B: Long-term postoperative outcomes of hypersplenism: Laparoscopic versus open splenectomy secondary to liver cirrhosis. Surg Endosc 26(12): 3391-3400, 2012.

39 Dominguez EP, Choi YU, Scott BG, Yahanda AM, Graviss EA and Sweeney JF: Impact of morbid obesity on outcome of laparoscopic splenectomy. Surg Endosc 21(3): 422-426, 2007.

40 Aksu T, Erdem AY, Fettah A, Kacar D, Avci Z, Yarali N and Tunc B: Massive splenic infarction and portal vein thrombosis in children with chronic myeloid leukemia. J Pediatr Hematol Oncol 36(7): e471-472, 2014.

41 Patrono D, Benvenga R, Moro F, Rossato D, Romagnoli R and Salizzoni M: Left-sided portal hypertension: Successful management by laparoscopic splenectomy following splenic artery embolization. Int J Surg Case Rep 5(10): 652-655, 2014.

42 Zhou J, Liu P, Yin Z, Zhao Y and Wang X: Safety and costeffectiveness analysis of laparoscopic splenectomy by secondary pedicle division using monopolar electrocautery. Hepatogastroenterology 60(126): 1302-1306, 2013.

43 Cordera F, Long KH, Nagorney DM, McMurtry EK, Schleck C, Ilstrup D and Donohue JH: Open versus laparoscopic splenectomy for idiopathic thrombocytopenic purpura: Clinical and economic analysis. Surgery 134(1): 45-52, 2003.

44 Leo CA, Pravisani R, Bidinost S, Baccarani U, Bresadola V, Risaliti A and Terrosu G: Postsplenectomy recurrence of idiopathic thrombocitopenic purpura: Role of laparoscopic splenectomy in the treatment of accessory spleen. G Chir 36(4): 153-157, 2015.

45 Navez J, Hubert C, Gigot JF, Navez B, Lambert C, Jamar F, Danse E, Lannoy V and Jabbour N: Does the site of platelet sequestration predict the response to splenectomy in adult patients with immune thrombocytopenic purpura? Platelets 26(6): 573-576, 2015.

46 Cai Y, Liu X and Peng B: Should we routinely transfuse platelet for immune thrombocytopenia patients with platelet count less than $10 \times 10^{9} / 1$ who underwent laparoscopic splenectomy? World J Surg 38(9): 2267-2272, 2014. 
47 Rijcken E, Mees ST, Bisping G, Krueger K, Bruewer M, Senninger N and Mennigen R: Laparoscopic splenectomy for medically refractory immune thrombocytopenia (ITP): A retrospective cohort study on longtime response predicting factors based on consensus criteria. Int J Surg 12(12): 1428-1433, 2014.

$48 \mathrm{Xu} \mathrm{T}, \mathrm{Li} \mathrm{N}$, Jin F, Wu K and Ye Z: Predictive factors of idiopathic thrombocytopenic purpura and long-term survival in Chinese adults undergoing laparoscopic splenectomy. Surg Laparosc Endosc Percutan Tech 26(5): 397-400, 2016.

49 Antel KR, Panieri E and Novitzky N: Role of splenectomy for immune thrombocytopenic purpura (ITP) in the era of new second-line therapies and in the setting of a high prevalence of HIV-associated ITP. S Afr Med J 105(5): 408-412, 2015.

50 Gossot D, Fritsch S and Celerier M: Laparoscopic splenectomy: Optimal vascular control using the lateral approach and ultrasonic dissection. Surg Endosc 13(1): 21-25, 1999.

51 Park A, Gagner $M$ and Pomp A: The lateral approach to laparoscopic splenectomy. Am J Surg 173(2): 126-130, 1997.

52 Trias M, Targarona EM and Balague C: Laparoscopic splenectomy: An evolving technique. A comparison between anterior and lateral approaches. Surg Endosc 10(4): 389-392, 1996.

53 Wang H, Kopac D, Brisebois R, Sample C and Shapiro AM: Randomized controlled trial to investigate the impact of anticoagulation on the incidence of splenic or portal vein thrombosis after laparoscopic splenectomy. Can J Surg 54(4): 227-231, 2011.

54 Davies JM, Barnes R, Milligan D and British Committee for Standards in Haematology. Working Party of the Haematology/ Oncology Task F: Update of guidelines for the prevention and treatment of infection in patients with an absent or dysfunctional spleen. Clin Med 2(5): 440-443, 2002.

55 Barosi G, Ambrosetti A, Buratti A, Finelli C, Liberato NL, Quaglini S, Ricetti MM, Visani G, Tura S and Ascari E: Splenectomy for patients with myelofibrosis with myeloid metaplasia: Pretreatment variables and outcome prediction. Leukemia 7(2): 200-206, 1993.

56 Brigden ML and Pattullo AL: Prevention and management of overwhelming postsplenectomy infection--an update. Crit Care Med 27(4): 836-842, 1999.

57 Gelmini R, Romano F, Quaranta N, Caprotti R, Tazzioli G, Colombo G, Saviano M and Uggeri F: Sutureless and stapleless laparoscopic splenectomy using radiofrequency: Ligasure device. Surg Endosc 20(6): 991-994, 2006.
58 Kaplinsky C and Spirer Z: Post-splenectomy antibiotic prophylaxis--unfinished story: To treat or not to treat? Pediatr Blood Cancer 47(5 Suppl): 740-741, 2006.

59 Pardhan A, Hameed A, Zafar H, Mazahir S and Murtaza G: Outcomes of splenectomy for idiopathic thrombocytopenic purpura in adults: A developing country perspective. J Pak Med Assoc 64(11): 1240-1243, 2014.

60 Waghorn DJ: Overwhelming infection in asplenic patients: Current best practice preventive measures are not being followed. J Clin Pathol 54(3): 214-218, 2001.

61 Rodeghiero F, Stasi R, Gernsheimer T, Michel M, Provan D, Arnold DM, Bussel JB, Cines DB, Chong BH, Cooper N, Godeau B, Lechner K, Mazzucconi MG, McMillan R, Sanz MA, Imbach P, Blanchette V, Kuhne T, Ruggeri M and George JN: Standardization of terminology, definitions and outcome criteria in immune thrombocytopenic purpura of adults and children: Report from an International Working Group. Blood 113(11): 2386-2393, 2009.

62 Vecchio R, Intagliata E, La Corte F, Marchese S, Cacciola RR and Cacciola E: Late results after splenectomy in adult idiopathic thrombocytopenic purpura. JSLS 19(1): e2013.00272, 2015.

63 Grossbard ML: Is laparoscopic splenectomy appropriate for the management of hematologic and oncologic diseases? Surg Endosc 10(4): 387-388, 1996.

64 Winslow ER and Brunt LM: Perioperative outcomes of laparoscopic versus open splenectomy: A meta-analysis with an emphasis on complications. Surgery 134(4): 647-653; discussion 654-645, 2003

65 Romano F, Caprotti R, Conti M, Piacentini MG, Uggeri F, Motta V, Pogliani EM and Uggeri F: Thrombosis of the splenoportal axis after splenectomy. Langenbecks Arch Surg 391(5): 483-488, 2006.

66 Kojouri K, Vesely SK, Terrell DR and George JN: Splenectomy for adult patients with idiopathic thrombocytopenic purpura: A systematic review to assess long-term platelet count responses, prediction of response, and surgical complications. Blood 104(9): 2623-2634, 2004 